\title{
Screening of Hybrid Jatropha curcas L. Genotypes for Drought Tolerant Abilities as a Source of Superior Variety Characteristics
}

\author{
Erfan Dani Septia ${ }^{1,2 *}$, Siti Rofidah ${ }^{3}$, Sofyan Arief $^{4}$ and Maftuchah ${ }^{1,2}$ \\ ${ }^{1}$ Center of Biotechnology Development, University of Muhammadiyah Malang, Indonesia; ${ }^{2}$ Department of \\ Agrotechnology, Faculty of Agriculture and Animal Science, University of Muhammadiyah Malang, Indonesia; \\ ${ }^{3}$ Department of Pharmacy, Faculty of Health Sciences, University of Muhammadiyah Malang, Indonesia; \\ ${ }^{4}$ Department of Law, Faculty of Law, University of Muhammadiyah Malang, Indonesia
}

*Corresponding author: erfandani@umm.ac.id

\begin{abstract}
The scarcity of fuel oil in the future needs to be anticipated by preparing alternative energy. One of the alternative energy sources developed is Jatropha. However, the development of Jatropha should use marginal land as a cultivation area, like a dry land, because the food crops and horticulture use productive land for cultivation. Furthermore, Jatropha development through breeding is an effort to obtain superior varieties as biodiesel producers. This study aimed to determine the best phenotype characteristics of hybrid Jatropha plants as superior candidate trees. This research applied a descriptive qualitative method to determine the characteristics of Jatropha crossing results. The Jatropha characterization was conducted at the experimental garden of Kedung Pengaron Village, Kejayan Sub-district, Pasuruan Regency. The experimental garden was included dry land for Jatropha cultivation. The result showed ten selected genotypes of hybrid Jatropha were found, including 05.01.01, 05.01.02, 05.02.02, 05.02.09, 05.03.17, 05.03.16, 05.04.16, 05.04.15, 06.01.02, 06.01.15. These were based on the two-phase observations, consisting of vegetative and generative observations. The plants' morphological characters were observed, comprising the stems, leaves, flowers, fruits and seeds. In the vegetative phase, diversity was found in the number of leaves, leaf length and age of flowering, while in the qualitative phase, the shoot colors were more diverse. Moreover, less variations were figured out in the color character of the petiole and the number of shoots. These ten genotypes of hybrid Jatropha are the best genotypes that are resistant to drought with selected agronomic characters.
\end{abstract}

Keywords: biodiesel crop; drought stress; genetic diversity; Jatropha curcas L.

Cite this as: Septia, E. D., Rofidah, S., Arief, S., \& Maftuchah. (2021). Screening of Hybrid Jatropha curcas L. Genotypes for Drought Tolerant Abilities as a Source of Superior Variety Characteristics. Caraka Tani: Journal of Sustainable Agriculture, 36(1), 188-200. doi: http://dx.doi.org/10.20961/carakatani.v36i1.38634

\section{INTRODUCTION}

Indonesia is a developing country that has a tropical climate with abundant natural resources. The development of the agriculture and energy sector is highly necessary. In Indonesia, 49 types of plants are potential as energy sources, such as biodiesel, bioethanol and bio-oil (Maftuchah et al., 2013). Some possible plants that can be taken advantages as biodiesel are oil palm, coconut, canola, cassava, sugar cane, corn and Jatropha. Some of these plants are classified as food plants. The development of food crops as energy sources is considered unethical and therefore, the selected commodities that are not included as food commodities are quickly

\footnotetext{
${ }^{*}$ Received for publication January 6, 2020

Accepted after corrections January 23, 2021
} 
developed massively and sustainably (Maftuchah et al., 2020).

Jatropha curcas L. is a potential plant used to produce raw materials for biofuels or biodiesel. These plants grow well on critical land or marginal environments (Mulpuri et al., 2019). The dry land indicates "marginality" due to water stress. In general, the abandoned agricultural land where food production is not economical and has low inherent productivity potential is considered marginal. However, most Jatropha plants are grown on marginal lands, such as dry land. This shows that the land used for Jatropha cultivation is land other than productive land for food crops and horticulture. The development of Jatropha plants through breeding is one way to obtain superior varieties. Surahman et al. (2010) reported that Jatropha is potential as an alternative vegetable raw material because the seeds contain relatively high oil (20-40\%), while in the kernel ranges from 50-60\%. Jatropha has several advantages to be developed as a source plant for biodiesel. This type of plant has a high tolerance to grow and produce on marginal land, is relatively more resistant to drought, is toxic so that livestock dislikes it and pest attacks to this plant are relatively lower when compared to other cultivated plants (Wijaya et al., 2013).

The potential of Jatropha can continue to be developed if the plants have great quality and agronomic properties. Breeding is one solution to get good agronomic properties on Jatropha. Thus, it obtained the quality of jatropha oil production. The developed varieties can become intellectual property rights for the beginner (Maftuchah et al., 2017a). The characters of the plant to be registered must be clear. A variety can be protected if it can be clearly defined. Only clearly defined varieties can be processed to obtain Plant Variety Protection (PVP) rights. The varieties that are eligible for PVP include varieties of new, unique, uniform, stable and named species. One method in characterizing the varieties of Jatropha plants is by identifying the morphological signs, namely qualitative characters (Surahman et al., 2010). Therefore, the characteristics of a plant are described through various studies, one of which is the BUSS test. The BUSS test in this study is limited to its unique nature, namely testing the diversity of morphological and anatomical characters (Khadijah, 2016).
One of the strategies to support the development of the Jatropha plants is by providing high-yielding varieties with high productivity by crossing or hybridizing plants that have superior characters. The target of the Jatropha plant breeding to produce high yield can be achieved if there is a basic population that has high genetic diversity, especially in the characters related to crop yields (Hartati and Heliyanto, 2011). Genetic diversity in a Jatropha plant population is essential because it is a genetic wealth that can be used to obtain new high-yielding varieties. Besides, genetic diversity is the basis for developing and improving plants. Germplasm is needed in determining the crossing elders to assemble hybrid varieties (Novita, 2013). The size of the genetic diversity of germplasm can support the Jatropha breeding program.

Yulaikah and Purwati (2010) have carried out the morphological characterization of 126 Jatropha accessions in the Asembagus Experimental Garden, Situbondo, with the results of all accessions observed having green leaf color. In the other leaf characters, there are two accession groups with a leaf surface and a rather bent (wavy) leaf, three accession groups with leaf numbers 3,5 and 7 and two accession groups with red and reddish shoots. Some researchers also found that variations in the weight of the seeds has a correlation with oil content (Nietsche et al., 2014). The variations in oil content between $4-34 \%$ were obtained by Cardoso et al. (2018). Hartati et al. (2012) noticed the variations in plant height, stem circumference, branching, flowering age, number of inflorescences, number of fruit bunches, number of fruits and number of seeds. Some variations were also investigated in leaf shape, number of leaf curves, shoot color, flower petal color and number of seed spaces per fruit.

This study aims at determining the best phenotype characters of hybrid Jatropha plants as superior candidate trees. The best ten variations are resulted from JC UMM5 with the highest seed production in drought conditions. The urgency of the research lies in its primacy, that the characteristics and potentials of the Jatropha plants that have been crossed to produce new superior varieties are not yet known and therefore, the efforts to characterize hybrid Jatropha plants become the virtues in this study. 


\section{MATERIALS AND METHOD}

\section{Place and time of the research}

The research activities were carried out in January-June 2019 at the experimental garden of Kedung Pengaron Village, Kejayan Subdistrict, Pasuruan Regency, with site location of 7०45'54.3" South Latitude, 112 ${ }^{\circ} 50^{\prime} 37.7^{\prime \prime}$ East longitude and Biotechnology Laboratory, University of Muhammadiyah Malang, Indonesia.

\section{Research materials}

Research on the characterization of Jatropha plants of several JC UMM genotypes with various numbers of crossing results has not been carried out. JC UMM is a genotype parent of Jatropha with higher average characters in fruit bunches, fruit number, dry weight of seeds, dry weight of 100 seeds and seed oil content. This parent produces several results, one of which is JC UMM5. Information on the characteristics of JC UMM5 has been available from the Agricultural Research and Development Agency. Notwithstanding, in the tests carried out, it is necessary to re-characterize the genotype as a similar phenotype.

The research materials were 10 Jatropha plant genotypes and JC UMM5 Jatropha plants, Jatropha leaves, Jatropha stems, Jatropha seeds, cow manure and inorganic fertilizers (Urea and Phonska), insecticides and fungicides. The tools used in this study included agricultural equipment, analytical scales, ovens and measuring cups. The tools for data collection and measurement were stationery, meters/rulers, calipers, Munsell Plant Tissue Color Book (Ferguson, 2012), etc. The supporting equipment covered cameras, plant labels, ink eraser, research identity boards, data collection books and calculators.

\section{Research implementation}

This study applied direct observation methods for each individual by directly identifying the plants' organs. In this study, the identification of ten Jatropha genotypes was repeated four times.

\section{Plant propagation}

Jatropha seeding was done through stem cuttings. The planting was carried out in polybags with the composition media used in the form of soil (humus), husks and manure with a ratio of 1: $1: 1$. The planting material used were woody shoots ( \pm 1 -year old), green to a gray in color with $\pm 30-40 \mathrm{~cm}$ long cuttings and $\pm 1.5-2.5 \mathrm{~cm}$ in diameter.

2. Planting and maintenance

The seeds from stem cuttings were given special treatments before entering the planting stage, namely soaking at the lower end of the cuttings using a mixed solution of water, Rootone $\mathrm{F}$ and fungicide (Ridomil) for \pm 24 hours. After that, the cuttings were planted in polybags containing media with a depth of $\pm 10-15 \mathrm{~cm}$. The polybags were labeled by the variety, replication and sample. Meanwhile, for each bed, a label was attached, showing the number of propagations and the date of planting. Plant maintenance included fertilization, irrigation, weeding and pest control.

\section{Observation characterization of hybrid Jatropha plant}

The observation of the qualitative characters in this study was used to identify the main characteristics of an accession because the trait was not or slightly influenced by the environment. These qualitative traits generally include morphological and botanical properties. Some qualitative properties of the Jatropha plant are shoot color, leaf color, leaf edge, leaf shape and stem color, while the quantitative nature, in general, is strongly influenced by the environment, including the quality of physiology and agronomy. Some important quantitative characteristics of Jatropha and the like are the number of female inflorescence, number of plant capsules, number of seeds per fruit, weight of 1,000 seeds, oil content and number of plants per hectare (Mahmud et al., 2009).

The variables used in this study were the qualitative characters (Anggraeni and Heliyanto, 2015), which included:

1. The morphological character of the stem, which consisted of the color of the upper stem and the color of the lower stem;

2. The morphological characters of leaves, which covered the color of young leaves that had not been fully opened, the color of old leaves that were fully open, the color of the upper leaf bone, the leaf stalk color of the upper surface, the shape of the leaf, the feathers on the leaf, the shape of the leaf base, the shape of the leaf tip, the degree leaf curve, leaf green intensity, intensity of anthocyanin staining on leaf stalk, 
color of lower leaf stalk, leaf color seen as a whole and direction of leaf tip;

3. The morphological character of the flower, which comprised the type of flowering, the fruit morphology, which encompassed the color of young fruit, the color of ripe fruit, fruit shape and the seed morphology, which covered the color of the ripe seed coat, seed shape, rough or dull seed coat, shiny or not seed coat.

\section{Data analysis}

The results of observation of qualitative characters were used describe the characters of each genotype, while the percentage of similarity was measured using cluster analysis with the NTSYSpc 2.02 program based on the scoring data of each character.

\section{RESULTS AND DISCUSSION}

\section{The results of the selection of the selected} hybrid Jatropha curcas

Based on the observations, 40 Jatropha plants resulted ten hybrids from four replications, namely genotypes $05.01 .01,05.01 .02,05.02 .02$, 05.02.09, 05.03.17, 05.03.16, 05.04.16, 05.04.15, 06.01.02, 06.01.15. The results were based on observations on the morphological characters, including stems, leaves, flowers, fruits and seeds. Figure 1 presents the results obtained from the selection of Jatropha hybrid plants.

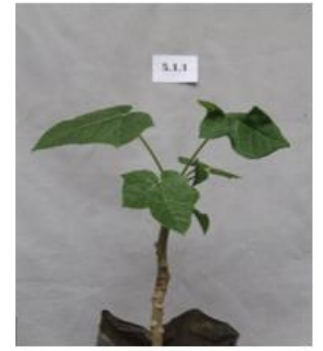

05.01 .01

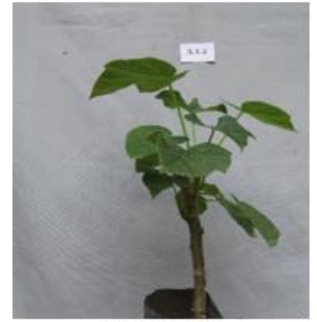

05.01 .02

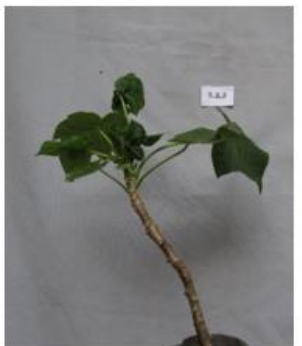

05.02 .02

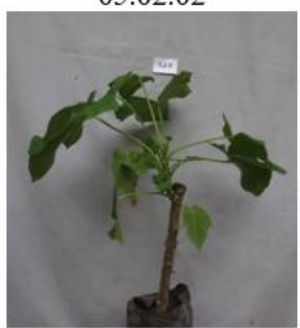

05.02 .09

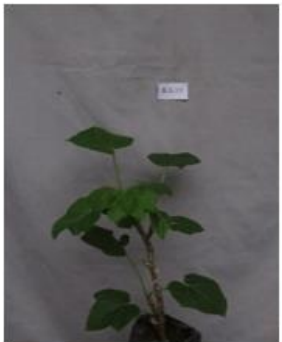

05.03 .17

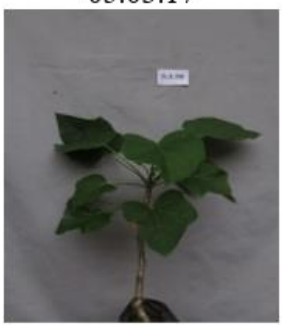

05.03.16

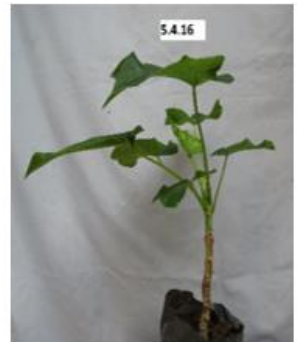

05.04.16

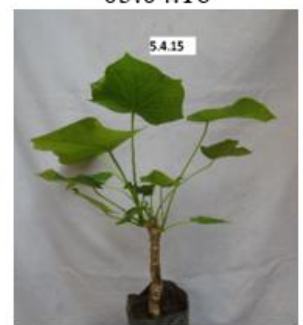

05.04 .15

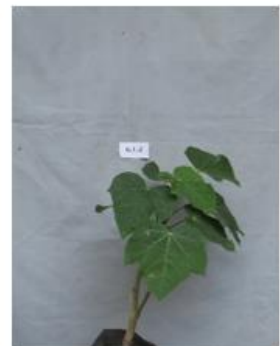

06.01 .02

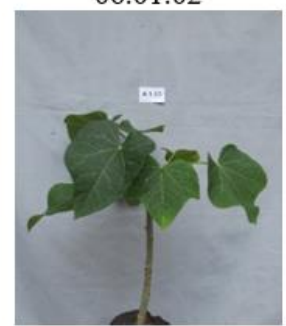

06.01 .15

Figure 1. The results of ten selected hybrid Jatropha plants

Figure 1 shows a significant difference in growth, which was described in the morphology of Jatropha plants cultivated on dry land. The Jatropha variation reflected the morphological character as a productive plant even though it was planted on dry land for oil production. Santoso et al. (2014) reported that different vegetative and generative characteristics in growth were influenced by several environmental factors like variations of water availability. The characterization in the vegetative and generative phases is presented in Table 1-5.

Furthermore, variations in morphological characterization between accessions of Jatropha, which then contributed to a different natural agronomy of this plant. Variations between accessions happened because of the coming out of sprouts on the surface of the soil, age of deciduous cotyledon leaves, plant height, number of primary and secondary branches, age at first flowering, total number of flowers per bunch, number of capsules per bunch and per plant, simultaneity in capsule maturation, weight of 100 seeds and weight of dried seeds per plant and yield per hectare. From a total of 50 characters observed, there was a difference of 27\% (Santoso, 2010). In particular, Santoso's study (2014) in NTB revealed that the genotypes from West Lombok (now North Lombok), Sumbawa and Bima had a better production potential than the genotypes from Central Lombok and East Lombok. The differences in the production potential of Jatropha were highly dependent on the genotype and 
provenance, as well as the differences in environment and genetic factors of each Jatropha accession (Santoso et al, 2014). The study also found that the morphological characteristics of each Jatropha was stable. This stability was not only determined by the similarity in the environmental factors between the locations of origin of the ecotype, but also by the factor of the reproduction behavior of Jatropha.

\section{Characterization of ten hybrid Jatropha plants}

The characterization of selected Jatropha plants with ten selected hybrids included the average plant height, stem diameter, canopy diameter, stem color and number of primary branches (Table 1).

Table 1. Average plant height, stem diameter, canopy diameter, stem color and number of primary branches

\begin{tabular}{cccccc}
\hline Genotype & $\begin{array}{c}\text { Average } \\
\text { plant height } \\
(\mathrm{cm})\end{array}$ & $\begin{array}{c}\text { Average stem } \\
\text { diameter } \\
(\mathrm{cm})\end{array}$ & $\begin{array}{c}\text { Average canopy } \\
\text { diameter } \\
(\mathrm{cm})\end{array}$ & $\begin{array}{c}\text { Bar } \\
\text { color }\end{array}$ & $\begin{array}{c}\text { Average number } \\
\text { of primary } \\
\text { branches }\end{array}$ \\
\hline 05.01 .01 & 34.17 & 1.6 & 32.33 & $2.5 \mathrm{GY} 5 / 8$ & 1 \\
05.01 .02 & 37.67 & 1.8 & 27.67 & $5 \mathrm{GY} 6 / 10$ & 2 \\
05.02 .02 & 36.67 & 1.7 & 27.67 & $5 \mathrm{Y} \mathrm{5/2}$ & 1 \\
05.02 .09 & 38.67 & 1.8 & 24.67 & $5 \mathrm{Y} \mathrm{5/2}$ & 2 \\
05.03 .17 & 46.67 & 1.7 & 29.67 & $5 \mathrm{GY} 7 / 10$ & 2 \\
05.03 .16 & 45.00 & 1.5 & 37.33 & $2.5 \mathrm{GY} 6 / 2$ & 1 \\
05.04 .16 & 50.87 & 1.9 & 35.00 & $5 \mathrm{Y} \mathrm{6/2}$ & 2 \\
05.04 .15 & 53.60 & 1.9 & 33.33 & $5 \mathrm{GY} \mathrm{6/4}$ & 1 \\
06.01 .02 & 44.67 & 1.7 & 30.33 & $5 \mathrm{GY} \mathrm{6/10}$ & 2 \\
06.01 .15 & 47.83 & 1.7 & 34.33 & $2.6 \mathrm{GY} 6 / 8$ & 1 \\
\hline
\end{tabular}

Note: Color : Y = yellow, GY = green yellow. Color character refers to Munsell Plant Tissue Color Book (Wilde and Voigt, 2012)

Krishnamurthy et al. (2013) reported significant differences in phenotypic information against the breeding environment. Those traits are plant height, plant canopy, collar diameter, number of primary and secondary branches, average seed weight, number of seeds and capsules, seed yield and oil content. Jatropha stems are long, round and green-gray. The old stems have dead and peeled-off skin (Santoso, 2010). Jatropha stems are woody and cylindrical and produce sap (Purwati et al., 2015). Jatropha is a shrub plant with $100-700 \mathrm{~cm}$ height and irregular branching (Taryono et al., 2019). The results of observation on the characters of plant height show that the height of 10 Jatropha plant genotypes ranged between $34.17 \mathrm{~cm}$ and $53.60 \mathrm{~cm}$. Genotype 05.04 .15 had the largest average plant height of $53.60 \mathrm{~cm}$, while genotype 05.01.01 had the shortest plant size of $34.17 \mathrm{~cm}$.

Stem diameter is the most easily measured plant dimension, especially at the bottom, using calipers. The observations showed that the largest diameter, $1.9 \mathrm{~cm}$, was found in genotypes 05.04.16 and 05.04.15, while the narrowest stem diameter, $1.6 \mathrm{~cm}$, was found in genotype 05.01.01. Plant height has a very significant relationship with stem diameter, meaning that increasing diameter will increase plant height. This is not in line with the results of the study, where the genotype with the largest diameter does not have tall stem. Jatropha has irregular branching, consisting of primary branches as the main branches and branches that are first formed, secondary branches formed on the primary branches and where the terminal branches grow and terminal branches where the leaves, flower and fruit grow (De Azevedo Peixoto et al., 2017).

Plants continue to grow depending on the availability of a growth meristem in plants. This is consistent with the results of the study that signifies a positive correlation between stem diameter and branch production, indicating that the greater the diameter of the Jatropha stem is, the higher the branch production will be. This is because plants with a larger diameter have more roots and faster root growth rate that contribute to higher absorption of water and food substances. When more water and food substances are 
absorbed by plants, more carbon is produced through photosynthesis (Krishnamurthy et al., 2013). Canopy diameter is influenced by the number of primary branches, where more branches produced by plants will cause the growth to tend to sideways and widen. The number of branches is largely determined by the number of primary and secondary branches formed (Purwati et al., 2015). Stem diameter has continuity with plant canopy, where large stem diameters are thought to be able to support the canopy better than small stem diameters (Hartati et al., 2012).

\section{Morphology of leaf}

Based on the results of the observations on leaf morphology, it can be seen that the average leaf length of Jatropha ranged from 8.27-13.03 cm, leaf width reaches $9.13-13.37 \mathrm{~cm}$, and the ratio of leaf length/width varied between 0.82 and 1.00 . Moreover, the color of young leaves measured with a color chart was red, the old leaf ranged from yellowish to green and the upper leaf bone was yellowish to green. In terms on shape, the leaf was round and heart, the leaf tip was tapered and the leaf base was curved. There were also feather found on young leaves and nicks (Table 2).

Table 2. Average leaf length, leaf width, leaf length/width ratio, young leaf color, old leaf color, upper leaf bone color, leaf shape, leaf tip shape, leaf base shape, the presence of feather on young leaves and the presence of nicks

\begin{tabular}{|c|c|c|c|c|c|c|c|c|c|c|c|c|}
\hline \multirow[b]{2}{*}{ Genotype } & \multicolumn{12}{|c|}{ Variable } \\
\hline & $\begin{array}{c}\text { Leaf } \\
\text { length } \\
(\mathrm{cm})\end{array}$ & $\begin{array}{c}\text { Leaf } \\
\text { width } \\
(\mathrm{cm})\end{array}$ & $\begin{array}{c}\text { Leaf } \\
\mathrm{L} / \mathrm{W} \\
\text { ratio } \\
\end{array}$ & $\begin{array}{c}\text { Stalk } \\
\text { length } \\
(\mathrm{cm})\end{array}$ & $\begin{array}{c}\text { Color of } \\
\text { young } \\
\text { leaves }\end{array}$ & $\begin{array}{c}\text { Old } \\
\text { leaf } \\
\text { color }\end{array}$ & $\begin{array}{l}\text { Color of } \\
\text { upper leaf } \\
\text { bone }\end{array}$ & $\begin{array}{c}\text { Leaf } \\
\text { shape }\end{array}$ & $\begin{array}{c}\text { Leaf } \\
\text { tip } \\
\text { shape }\end{array}$ & $\begin{array}{l}\text { Leaf } \\
\text { base } \\
\text { shape }\end{array}$ & $\begin{array}{c}\text { Feather } \\
\text { on young } \\
\text { leaves }\end{array}$ & Nicks \\
\hline 05.01 .01 & 8.77 & 9.67 & 0.91 & 8.9 & $5 \mathrm{R} 3 / 6$ & 7.5 GY $3 / 4$ & $2.5 \mathrm{GY} 8 / 8$ & Round & Tapered & Curved & Exist & Exist \\
\hline 05.01 .02 & 9.33 & 10.63 & 0.88 & 10.7 & $5 \mathrm{R} 3 / 6$ & $7.5 \mathrm{GY} 3 / 4$ & $2.5 \mathrm{GY} 8 / 8$ & Round & Tapered & Curved & Exist & Exist \\
\hline 05.02 .02 & 9.43 & 11.00 & 0.86 & 10.6 & $5 \mathrm{R} 3 / 6$ & 7.5 GY $3 / 4$ & $2.5 \mathrm{GY} 8 / 6$ & Round & Tapered & Curved & Exist & Exist \\
\hline 05.02 .09 & 9.33 & 10.83 & 0.86 & 9.3 & $5 \mathrm{R} 3 / 6$ & 7.5 GY $3 / 4$ & $2.5 \mathrm{GY} 8 / 6$ & Round & Tapered & Curved & Exist & Exist \\
\hline 05.03 .17 & 9.03 & 10.17 & 0.89 & 11.4 & $5 \mathrm{R} 3 / 6$ & 7.5 GY $4 / 4$ & $2.5 \mathrm{GY} 8 / 6$ & Round & Tapered & Curved & Exist & Exist \\
\hline 05.03 .16 & 8.27 & 10.13 & 0.82 & 10.7 & $5 \mathrm{R} 3 / 6$ & 7.5 GY $4 / 4$ & $2.5 \mathrm{GY} 8 / 6$ & Round & Tapered & Curved & Exist & Exist \\
\hline 05.04 .16 & 8.47 & 9.13 & 0.93 & 9.4 & $5 \mathrm{R} 3 / 6$ & $7.5 \mathrm{GY} 4 / 4$ & $2.5 \mathrm{GY} 8 / 8$ & Heart & Tapered & Curved & Exist & Exist \\
\hline 05.04 .15 & 13.03 & 13.73 & 0.95 & 13.8 & $5 \mathrm{R} 3 / 6$ & 7.5 GY 4/4 & $2.5 \mathrm{GY} 8 / 8$ & Round & Tapered & Curved & Exist & Exist \\
\hline 06.01 .02 & 10.63 & 10.60 & 1.00 & 11.3 & $5 \mathrm{R} 3 / 6$ & $7.5 \mathrm{GY} 4 / 4$ & $2.5 \mathrm{GY} 8 / 8$ & Round & Tapered & Curved & Exist & Exist \\
\hline 06.01 .15 & 11.37 & 11.60 & 0.98 & 13.8 & $5 \mathrm{R} 3 / 6$ & $7.5 \mathrm{GY} 4 / 4$ & $2.5 \mathrm{GY} 8 / 8$ & Heart & Tapered & Curved & Exist & Exist \\
\hline
\end{tabular}

Note: Color: $\mathrm{R}=$ red, GY = green yellow. Color characters refer to the Munsell Plant Tissue Color Book (Wilde and Voigt, 2012)

The leaf is an important part of the plant and in general each plant has a large number of leaves. The leaves are usually thinly widened, rich in a green dye called chlorophyll (Tjitrosoepomo, 2010). Genotype 05.04.15 had the most significant leaf width. The presence of shade will contributes to an increase in the area and shape of the leaves to streamline the incoming light catches, so that the growth of the canopy is faster (Maftuchah et al., 2012). Besides, the expansion in the leaf surface correlates with an increase in the number chloroplasts and the amount of chlorophyll. As presented in Table 2 , an increase in the number of chloroplasts affected by leaf color was found in ten young and old genotypes, with the same color of red for young leaf and green yellow for old leaf. Wijaya et al. (2013) also reported that the Jatropha genotypes had the same young and old leaf colors, namely green yellow. However, all observed genotypes had various colors of leaf buds, old leaves and leaf stems.
The observations also recorded that the Jatropha leaves were curved and had single angles of 3 or 7 . The leaves spread along and were arranged alternately on the stem to form a spiral. The leaves were light green to dark green in color. The top and bottom surfaces were paler than the top surfaces, which were slippery and somewhat hairy. The leaves were broad and heartshaped or ovoid in width, with almost the same length and width reaching $5 \mathrm{~cm}$ to $15 \mathrm{~cm}$ and jagged or flat edges or leaf edges. The leaf strands were chopped and notched at an angle of $3^{\circ}$ or $5^{\circ}$. The base of the leaves was curved and the tips of the leaves were tapered. The bones of the fingers were fringed with 5-7 main leaf bones. Leaf stems connected the leaves. The length of the petiole was between $4 \mathrm{~cm}$ and $15 \mathrm{~cm}$ (Raju and Bahadur, 2013).

The results of observations on ten Jatropha plant genotypes confirm that nicks were found in the leaf organ and no hair was seen on young leaves. Leaf shape is a pattern formed from the 
meeting of the leaf edges. The ten Jatropha plant genotypes were similar in the characters of leaf shape, in which each genotype had a tapered leaf tip and a grooved base, with rounded leaves and heart shape. According to Tjitrosoepomo (2010), leaves are round if the ratio of display: width is $1: 1$. In the length/width $(\mathrm{L} / \mathrm{W})$ ratio, the leaves show genotype 6.1.2 have a ratio of $1: 1$. The petiole is the part of the leaf that supports the lamina and is tasked with placing the leaf blade in such a position that it can get as much sunlight as possible (Tjitrosoepomo, 2010). The character of the petiole is a unified xylem and phloem transport network system, which functions to channel nutrients from and water from the roots to the leaves and also functions in channeling the results of photosynthesis through the stems throughout the plant organs (Maftuchah et al., 2017b). Alfredo and Quintero (2017) concluded that Jatropha leaves contain leaf- related genes, such as Nal1 for controlling leaf width like leaf size, color and shape, respectively.

\section{Morphology of flower}

The results of morphological characterization of flowers are presented in Table 3. There were ten genotypes of Jatropha plants having similar characteristics in flower growth, male/female flower ratio and several flower branches. As well, the site of growing flowers was at the end of the terminal and the armpit. The rate of male and female flowers of all genotypes had a ratio of less than 1:18, with an average number of branches in the flower of 2. Jatropha flowers appeared when the plants began to be 3-4 months old. Flowering generally starts in the rainy season and in the dry season Jatropha undergo a withering process. The flowers appeared at the end of the stem, on the armpit of the leaf. The resulting flower was a panicle-shaped compound, greenish-yellow.

Table 3. The location of grown flowers, the ratio of male/female flowers, the number of branches on the flower, crown color and petal color

\begin{tabular}{|c|c|c|c|c|c|}
\hline \multirow[b]{2}{*}{ Genotype } & \multicolumn{5}{|c|}{ Variable } \\
\hline & $\begin{array}{l}\text { Location of grown } \\
\text { flowers }\end{array}$ & $\begin{array}{l}\text { Male/female } \\
\text { flower ratio }\end{array}$ & $\begin{array}{c}\text { Number of branches } \\
\text { on flower }\end{array}$ & $\begin{array}{l}\text { Crown } \\
\text { color }\end{array}$ & $\begin{array}{l}\text { Petal } \\
\text { color }\end{array}$ \\
\hline 05.01 .01 & $\begin{array}{l}\text { Terminal branch tips } \\
\text { and armpit leaves }\end{array}$ & $1: 18$ & 2 & $2.5 \mathrm{GY} 8 / 6$ & $2.5 \mathrm{GY} 8 / 10$ \\
\hline 05.01 .02 & $\begin{array}{l}\text { Terminal branch tips } \\
\text { and armpit leaves }\end{array}$ & $1: 18$ & 2 & $2.5 \mathrm{GY} 8 / 6$ & $2.5 \mathrm{GY} 8 / 10$ \\
\hline 05.02 .02 & $\begin{array}{l}\text { Terminal branch tips } \\
\text { and armpit leaves }\end{array}$ & $1: 18$ & 2 & $2.5 \mathrm{GY} 8 / 6$ & $2.5 \mathrm{GY} 8 / 10$ \\
\hline 05.02 .09 & $\begin{array}{l}\text { Terminal branch tips } \\
\text { and armpit leaves }\end{array}$ & $1: 18$ & 2 & $2.5 \mathrm{GY} 8 / 6$ & $2.5 \mathrm{GY} 8 / 10$ \\
\hline 05.03 .17 & $\begin{array}{l}\text { Terminal branch tips } \\
\text { and armpit leaves }\end{array}$ & $1: 18$ & 2 & $2.5 \mathrm{GY} 8 / 6$ & $2.5 \mathrm{GY} 8 / 10$ \\
\hline 05.03 .16 & $\begin{array}{l}\text { Terminal branch tips } \\
\text { and armpit leaves }\end{array}$ & $1: 18$ & 2 & $2.5 \mathrm{GY} 8 / 6$ & $2.5 \mathrm{GY} 8 / 10$ \\
\hline 05.04 .16 & $\begin{array}{l}\text { Terminal branch tips } \\
\text { and armpit leaves }\end{array}$ & $1: 18$ & 2 & $2.5 \mathrm{GY} 8 / 6$ & $2.5 \mathrm{GY} 8 / 10$ \\
\hline 05.04 .15 & $\begin{array}{l}\text { Terminal branch tips } \\
\text { and armpit leaves }\end{array}$ & $1: 18$ & 2 & $2.5 \mathrm{GY} 8 / 6$ & $2.5 \mathrm{GY} 8 / 10$ \\
\hline 06.01 .02 & $\begin{array}{l}\text { Terminal branch tips } \\
\text { and armpit leaves }\end{array}$ & $1: 18$ & 2 & $2.5 \mathrm{GY} 8 / 6$ & $2.5 \mathrm{GY} 8 / 8$ \\
\hline 06.01 .15 & $\begin{array}{l}\text { Terminal branch tips } \\
\text { and armpit leaves }\end{array}$ & $1: 18$ & 2 & $2.5 \mathrm{GY} 8 / 6$ & $2.5 \mathrm{GY} 8 / 8$ \\
\hline
\end{tabular}

Table 3 demonstrates that the flowers of observed Jatropha were categorized into male and female flowers, located in each panicle. The male and female flowers were on separate parts, at the ends of the flower stalks. Yahya et al. (2013) reported that female flowers are thickstemmed and have hairs like cobwebs and are larger in size than male flowers. The length of 
flower stalk reached 3-12 $\mathrm{cm}$ and each bunch contained more than 15 flowers, where the number of female flowers was 4-5 times more than male flowers. The flower had five ovalshaped petals, approximately $4 \mathrm{~mm}$ in length. The flower also had five purple-colored crowns. Male flowers had 8-10 stalks and the stamen gathered at the base and the cream head was creamy-yellow. Female flowers had three shortsized pistil stems with green color and the pistil protrudes yellow (Maftuchah et al., 2017a). In the observations, the ratio of female flowers and male flowers was obtained from equation and thus, it did not have a diversity ratio, which was 1: < 19. Maghuly et al. (2015) reported that the comparison of male and female flowers varied depending on the panicle size and environmental conditions.

\section{Morphology of fruit}

The outcomes of the morphological characterization of fruit are illustrated in Table 4. Table 4 exhibits diversity in fruit morphological characters, including fruit length, fruit width, length/width ratio, fruit shape, young fruit color and ripe fruit color.

Table 4. The average length of fruit stalk, fruit length, fruit width, fruit $1 / \mathrm{w}$ ratio, number of fruits per bunch, the color of ripe fruit

\begin{tabular}{ccccccc}
\hline \multirow{2}{*}{ Genotype } & \multicolumn{7}{c}{ Variable } \\
\cline { 2 - 7 } & $\begin{array}{c}\text { Long fruit } \\
\text { stalk }(\mathrm{cm})\end{array}$ & $\begin{array}{c}\text { Fruit length } \\
(\mathrm{mm})\end{array}$ & $\begin{array}{c}\text { Fruit width } \\
(\mathrm{mm})\end{array}$ & $\begin{array}{c}\text { Fruit L/W } \\
\text { ratio }\end{array}$ & $\begin{array}{c}\text { Number of fruits } \\
\text { per bunch }\end{array}$ & $\begin{array}{c}\text { Color of ripe } \\
\text { fruit }\end{array}$ \\
\hline 05.01 .01 & 5.4 & 26.3 & 25.3 & 1.04 & 1 & 5 Y $8 / 8$ \\
05.01 .02 & 7.4 & 27.0 & 23.9 & 1.13 & 2 & 5 Y $8 / 8$ \\
05.02 .02 & 8.3 & 25.5 & 21.2 & 1.20 & 1 & 5 Y $8 / 8$ \\
05.02 .09 & 6.7 & 28.0 & 21.7 & 1.29 & 1 & 5 Y $8 / 8$ \\
05.03 .17 & 4.4 & 24.1 & 21.5 & 1.12 & 1 & 5 Y $8 / 8$ \\
05.03 .16 & 5.3 & 26.1 & 21.7 & 1.20 & 2 & 5 Y 8/8 \\
05.04 .16 & 6.5 & 28.3 & 26.8 & 1.06 & 2 & 5 Y $8 / 10$ \\
05.04 .15 & 5.9 & 28.0 & 25.9 & 1.08 & 1 & 5 Y 8/10 \\
06.01 .02 & 4.7 & 25.2 & 24.8 & 1.02 & 1 & 5 Y 8/8 \\
06.01 .15 & 6.4 & 26.1 & 22.4 & 1.17 & 2 & 5 Y 8/8 \\
\hline
\end{tabular}

Note: Color: $\mathrm{Y}=$ yellow. Color character refers to Munsell Plant Tissue Color Book (Wilde and Voigt, 2012)

Table 4 presents that the average length of the fruit stalks of ten Jatropha plant genotypes observed varied. Genotype 05.02.02 had the most extended fruit stalk, which was $8.3 \mathrm{~cm}$ in length, while genotype 05.03.17 had the shortest fruit stalk, with a length of $4.4 \mathrm{~cm}$.

The average fruit length (vertical diameter) of ten genotypes varied greatly. Genotype 05.04.16 was the largest in size, with the fruit length of $28.3 \mathrm{~mm}$. Meanwhile, genotype 05.03.17 was the smallest in size, with the fruit length of $24.4 \mathrm{~mm}$. The average fruit width (horizontal diameter) of ten genotypes also diverse. Genotype 05.04.16 had the highest fruit width of $26.8 \mathrm{~mm}$ and genotype 05.02.02 had the lowest fruit width of 21.2 $\mathrm{mm}$. Moreover, the fruit $\mathrm{p} / \mathrm{l}$ ratio shows that genotype 05.01.01 had the lowest rate of 1:1.04, while genotype 05.02.09 had the highest rate of $1: 1.29$.
The number of fruits per bunch of the ten Jatropha plant genotypes was less than four. Meanwhile, the color of ripe fruits of the ten genotypes, measured based on the color of Munsell Plant Tissue Color Book (Ferguson, 2012), varies. The colors were divided into two categories. The first category consisted of eight genotypes that had $5 \mathrm{Y}$ 8/8 petal color, while the second category comprised two genotypes with 5 Y 8/10 petal color.

Jatropha fruit is often referred to as a capsule or biological fruit of kendaga (rhegma) because of its properties such as the fruit is splitting and each part is easily separated from the chamber or space. Each fruit stalk contained about 5-20 or more. The fruit was square, ovate, green when young and yellowing when ripe and had 2-4 cm diameter. Each fruit had 2-3 seeds in each space of the fruit. The fruit commonly had four boxes and four seeds. The 
observation results show that most bunches contained three fruits each. More fruits formed in each panicle on each plant will contribute to a large number of seeds (Santoso, 2010).

\section{Morphology of seeds}

The observations on Jatropha fruits were performed when the fruits were ripe and hardened
Jatropha. The mean of the collected data was taken. The results of seed morphological analysis on ten Jatropha seed genotypes are presented in Table 5, showing a variety of seed morphological characters, which include seed length, seed width, seed length/width ratio, seed shape, seed texture and seed color.

Table 5. The average seed length, seed width, seed L/W ratio, seed shape, seed texture, seed color

\begin{tabular}{ccccccc}
\hline \multirow{2}{*}{ Genotype } & \multicolumn{7}{c}{ Variable } \\
\cline { 2 - 7 } & $\begin{array}{c}\text { Seed length } \\
(\mathrm{mm})\end{array}$ & $\begin{array}{c}\text { Seed width } \\
(\mathrm{mm})\end{array}$ & $\begin{array}{c}\text { Seed L/W } \\
\text { ratio }\end{array}$ & $\begin{array}{c}\text { Seed } \\
\text { shape }\end{array}$ & $\begin{array}{c}\text { Seed } \\
\text { texture }\end{array}$ & $\begin{array}{c}\text { Seed } \\
\text { color }\end{array}$ \\
\hline 05.01 .01 & 16.8 & 10.57 & 1.59 & Ellipse & Smooth & Black \\
05.01 .02 & 17.4 & 10.83 & 1.61 & Ellipse & Smooth & Black \\
05.02 .02 & 16.1 & 10.20 & 1.58 & Ellipse & Smooth & Black \\
05.02 .09 & 16.9 & 10.33 & 1.64 & Ellipse & Smooth & Black \\
05.03 .17 & 16.7 & 10.33 & 1.62 & Ellipse & Rough & Black \\
05.03 .16 & 17.2 & 11.33 & 1.52 & Ellipse & Rough & Black \\
05.04 .16 & 17.6 & 10.63 & 1.66 & Oval & Smooth & Black \\
05.04 .15 & 17.1 & 10.40 & 1.64 & Oval & Smooth & Black \\
06.01 .02 & 16.2 & 10.30 & 1.57 & Ellipse & Smooth & Black \\
06.01 .15 & 15.7 & 10.03 & 1.57 & Ellipse & Smooth & Black \\
\hline
\end{tabular}

Table 5 demonstrates that the average seed length (vertical diameter) of the ten observed Jatropha plant genotypes varied in size. Genotype 05.04.11 had the most considerable length of seeds, which reached $17.6 \mathrm{~mm}$, while genotype 05.02.02 had the shortest seed length of $16.1 \mathrm{~mm}$. The average size of seed width (horizontal diameter) of ten Jatropha plant genotypes also diverged. Genotype 05.03.16 had the highest width, reaching $11.33 \mathrm{~mm}$, while genotype 05.02.02 had the lowest width, which was $10.2 \mathrm{~mm}$.

Table 5 also presents that the seed shapes of the ten genotypes were categorized into elliptical and oval. All of the genotypes, except genotypes 05.04.16 and 05.04.15, had ovoid seeds. The seed textures of the genotypes fell into two categories, namely smooth and rough. Genotypes 05.03.17 and 05.03.16 had rough textures, while the other genotypes had soft surfaces. In terms of seed color, all genotypes had black seeds, particularly when the seeds were old.

Jatropha seeds were oval-shaped, blackishbrown, $2 \mathrm{~cm}$ in length, $1 \mathrm{~cm}$ in thickness and 0.4-0.6 grams seed ${ }^{-1}$ in weight. The seeds were dicotyledonous (dicots), having two embryonic leaves. In general, Jatropha seeds are composed of shell and kernel, in which embryos are stored (Maftuchah et al., 2017a).
Jatropha seeds are classified as orthodox. The seeds will be dormant for a month after being harvested. To break dormancy, the seeds are soaked in water for 12 hours before sowing. Enough humidity will cause the seeds to germinate in less than ten days. Jatropha germination is epigeal (embryo leaves appear above the surface) (Figueroa et al., 2015). Dry conditions can inhibit the process of flower formation and reduce the success of the formation of hedges, which has an impact on seed production. Jatropha plants produce various oil contents. Jatropha seed oil content is influenced by genotype and environment (Gedoan et al., 2011).

Figure 2 demonstrates three clusters of familial dendrogram of Jatropha in the vegetative phase, with the criteria of the number of leaves and stems. The cluster had 0.42 cophenetic distance. Group 1, which consisted of genotypes 05.02.02, 05.02.09 and 05.01.01, had a particular level of kinship relationship. In group 2, the kinship relationship was shown by the genotypes 05.01.02, 06.01.02, 05.04.16, 05.04.15, 06.01.15, while in Group 3, the kinship relationship occurred between 05.03.16 and 05.03.17. The research by Yakub et al. (2013) reported that all the agro-morphological characters measured quantitatively until the end of the vegetative phase 
included the diversity in the number of leaves, leaf length and age of flowering, while those in qualitative phase resulted in the more diverse shoot colors but less variations in the color character of the petiole and the number of shoots.

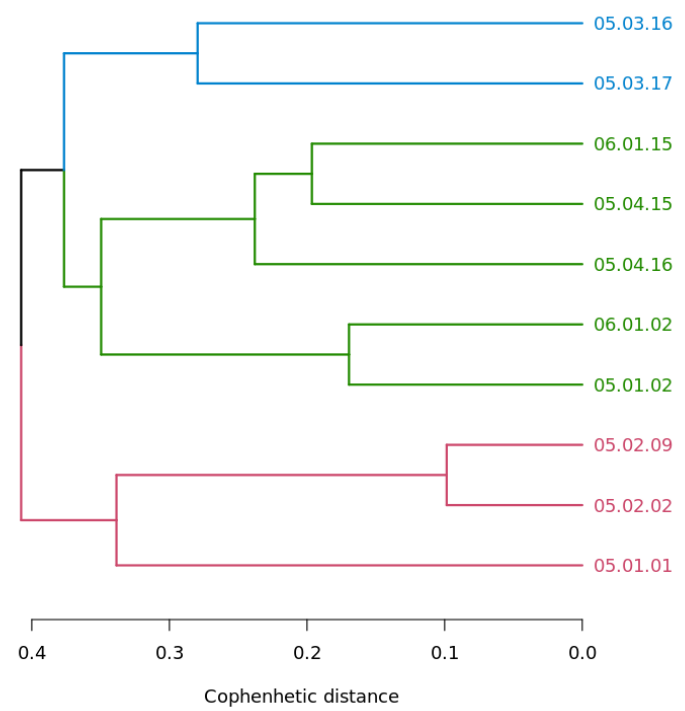

Figure 2. Dendrogram of Jatropha kinship (vegetative)

During the plant life cycle, there is a linear vegetative phase, which requires the longest time compared to the accelerated generative phase and the stagnant period for the maturation phase so that the plant's morphological features can be adequately represented (Carels et al., 2012). Generative and vegetative phases are different. In the rainy season, the production is higher than in the dry season. This signifies the significant interactions between genotypes and the environment (Maftuchah et al., 2018).

Figure 3 presents that the kinship relationships of Jatropha plants in the generative phase happen in three groups at various levels, including the characters of flowers, fruits and seeds. The kinship relationships occurred in Group 1 consisting of genotypes 05.01.01, 05.04.16, 05.04.15, Group 2 that included genotypes 05.01 .02 , 05.03.16 and 06.01.15, as well as Group 3 that covered genotypes 05.02.02, 05.02.09, 05.03.17 and 06.01.02. Genetic association and variability happened in seed and growth characters and it was found that male/female ratio had the highest positive relationship with seed yield in the generative phase (Tar et al., 2011). Jatropha plants have variations in leaf shape and color, stem bark, leaf stalk color, capsule shape and size, number of capsules/bunch, capsule compacting and number of seeds per capsule, capsule weight, number and weight of seeds per plant (Purwati et al., 2015).

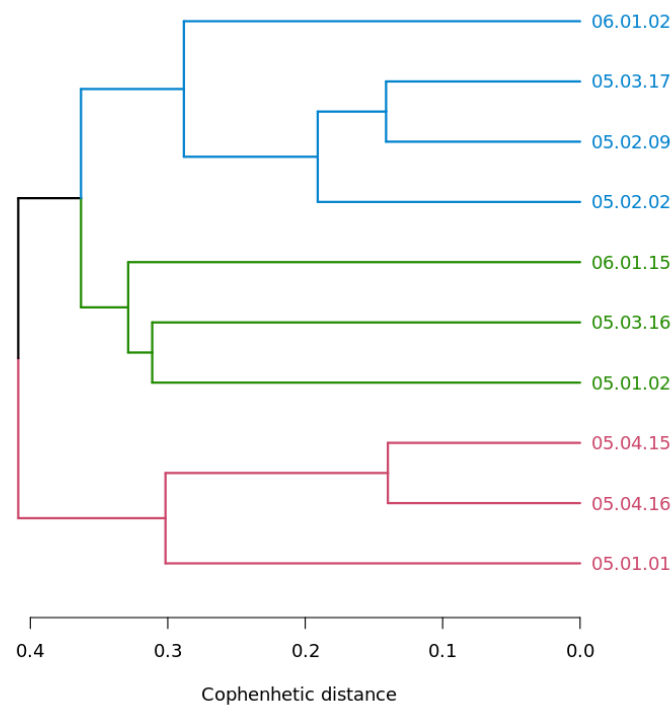

Figure 3. Dendrogram of Jatropha kinship (generative)

\section{CONCLUSIONS}

Based on this research, it can be concluded that the best of ten hybrid Jatropha genotypes found in this research are 05.01.01, 05.01.02, 05.02.02, 05.02.09, 05.03.17, 05.03.16, 05.04.16, 05.04.15, 06.01.02, 06.01.15. This plant has the ability to grow on dry land and good morphological characters, as indicated by the results of observations on vegetative and generative phases. These ten genotypes are the most resistant genotypes to drought with the selected agronomic characters.

\section{ACKNOWLEDGEMENT}

The author would like to thank the Directorate of Research and Community Service and the Center Biotechnology Development, University of Muhammadiyah Malang, for supporting and facilitating this internal research development 2019.

\section{REFERENCES}

Alfredo, Z. C., \& Quintero, V. P. (2017). New clonal varieties of Jatropha. In The Jatropha genome. Cham, Switzerland: Springer. https:// 
doi.org/10.1007/978-3-319-49653-5_16

Anggraeni, T. A. D. and Heliyanto, B. (2015). Status plasma nutfah jarak pagar (Jatropha curcas L.). In Bunga rampai: Inovasi teknologi jarak pagar penghasil bioenergi masa depan. Jakarta: IAARD Press. Retrieved from https://drive.google.com/file/d/0B2uQvI e9kM4taS1lcHZ6QXplbDQ/view

Cardoso, P. M. R., Dias, L. A. D. S., De Resende, M. D. V., De Freitas, R. G., Corrêa, T. R., Muniz, D. R., \& Zaidan, I. R. (2018). Genetic evaluation and selection in Jatropha curcas L. Crop Breeding and Applied Biotechnology, 18(2), 192-199. https://doi.org/10.1590/1984$70332018 \mathrm{v}$

$18 \mathrm{n} 2 \mathrm{a} 27$

Carels, N., Sujatha, M., \& Bahadur, B. (Eds.). (2012). Jatropha, challenges for a new energy crop: Volume 1: Farming, economics and biofuel. New York, USA: Springer Science \& Business Media. https://doi.org/10.1007/9781-4614-4806-8

De Azevedo Peixoto, L., Laviola, B. G., Alves, A. A., Rosado, T. B., \& Bhering, L. L. (2017). Breeding Jatropha curcas by genomic selection: A pilot assessment of the accuracy of predictive models. PLoS ONE, 12(3), e0173368. https://doi.org/10.1371/journal.pon e. 0173368

Ferguson, J. (2012). Color name diagrams for the munsell color charts for plant tissues. Canada: University of Toronto. Retrieved from http:// sites.utoronto.ca/tmap/Munsell/Color\%20Na me\%20Diagrams\%20for\%20the\%20Munsell $\% 20$ Color\%20Charts\%20for\%20Plant\%20Tis sues.pdf

Figueroa, S., Ramos, M., Ovando, V., \& Anaya, A. (2015). Genetic diversity and structure of Jatropha curcas L. in its centre of origin. Plant Genetic Resources, 13(1), 9-17. https://doi. org/10.1017/S1479262114000550

Gedoan, S. P., Hartana, A., Hamim, H., Widyastuti, U., \& Sukarno, N. (2011). Pertumbuhan jarak pagar (Jatropha curcas) pada lahan pasca tambang timah di Bangka yang diberi pupuk organik. Jurnal Ilmiah Sains, 11(2), 181-190. https://doi.org/ 10.35799/jis.11.2.2011.205
Hartati, R. S., \& Heliyanto, B. (2011). Keragaan F1 jarak pagar (Jatropha curcas L.) di Pakuwon, Sukabumi. In Prosiding Seminar Nasional Inovasi Perkebunan. Retrieved from http://perkebunan.litbang.pertanian.go.id/wpcontent/uploads/2012/04/perkebunan_prosdE NIP11_MP_SriH.pdf

Hartati, R. S., Setiawan, A., \& Heliyanto, B. S. (2012). Keragaman ganetik, heritabilitas, dan korelasi antar karakter 10 genotipe terpilih jarak pagar (Jatropha curcas L.). Jurnal Penelitian Tanaman Industri, 18(2), 74-80. http://dx.doi.org/10.21082/jlittri.v18n2.2012.7 4-80

Khadijah, N. (2016). Evaluasi keseragaman dan kestabilan lima varietas kacang panjang dalam Uji BUSS. Buletin Plasma Nutfah, 18(1), 1825. https://doi.org/10.21082/blpn.v18n1.2012. p18-25

Krishnamurthy, K. V., Venkatasubramanian, P., \& Lalitha, S. (2013). Laticifers of Jatropha. In Jatropha, challenges for a new energy crop: Volume 2: Genetic Improvement and Biotechnology. New York, NY, USA: Springer. https://doi.org/10.1007/978-1-46144915-7_1

Maftuchah, Zainudin, A., Ikhwan, A., Winaya, A., Purnama, A., \& Sudarmo, H. (2020). The potential of physic nut (Jatropha curcas Linn.) hybrid plant as a source of biodiesel at different planting location for dry land utilization. Energy Reports, 6, 921-926. https://doi.org/10.1016/j.egyr.2019.12.006

Maftuchah, Zainudin, A., Heliyanto, B., Sudarmo, H., Mel, M., \& Kuan, L. K. (2017a). Combining ability in Jatropha curcas L. genotypes. Proceedings of the Pakistan Academy of Sciences: Pakistan Academy of Sciences B. Life and Environmental Sciences, 54(3), 259-261. Retrieved from https://www. paspk.org/wp-content/uploads/2017/09/Comb ining-Ability.pdf

Maftuchah, Zainudin, A., Ishartati, E., \& Murdani, W. (2017b). Karakterisasi daun delapan genotipe jarak pagar (Jatropha curcas L.). In Prosiding Seminar Nasional dan Gelar Produk, Universitas Muhammadiyah Malang. Retrieved from http://research-report .umm.ac.id/index.php/research-report/article/ 
view/1265

Maftuchah, Zainudin, A., Ikhwan, A., Purnama, A., \& Kuan, L. K. (2018). Production capacity of several hybrid genotypes of Jatropha curcas Linn. for five years in Pasuruan, East Java - Indonesia. MATEC Web of Conferences, 164, 01026. https://doi.org/10. 1051/matecconf/201816401026

Maftuchah, Zainudin, A., \& Sudarmo, H. (2012). Pertumbuhan bibit dan produksi beberapa nomor hasil persilangan jarak pagar (Jatropha curcas L.). In EBTKE CONEX 2012. Retrieved from http://research-report.umm.ac.id/index. $\mathrm{php} /$ research-report/article/view/311

Maftuchah, Zainudin, A., \& Sudarmo, H. (2013). Production of physic nut hybrid progenies and their parental in various dry land. Agricultural Sciences, 4(1), 48-56. https://doi.org/10.4236/ as. 2013.41008

Maghuly, F., Jankowicz-Cieslak, J., Pabinger, S., Till, B. J., \& Laimer, M. (2015). Geographic origin is not supported by the genetic variability found in a large living collection of Jatropha curcas with accessions from three continents. Biotechnology Journal, 10(4), 536-551. https://doi.org/10.1002/biot. 201400196

Mahmud, Z., Hasnam, \& Hartati, R. S. (2009). Biologi dalam teknologi menjawab tantangan krisis energi. Jakarta: Pusat Penelitian dan Pengembangan Perkebunan, Badan Penelitian dan Pengembangan Pertanian.

Mulpuri, S., Carels, N., \& Bahadur, B. (2019). Jatropha, Challenges for a New Energy Crop: Volume 3: A Sustainable Multipurpose Crop. Singapore: Springer Nature. https://doi.org/ 10.1007/978-981-13-3104-6

Nietsche, S., Vendrame, W. A., Crane, J. H., \& Pereira, M. C. T. (2014). Assessment of reproductive characteristics of Jatropha curcas L. in South Florida. GCB Bioenergy, 6(4), 351-359. https://doi.org/10.1111/gcbb. 12051

Novita, L. (2013). Analisis genetik karakter morfo-agronomi jarak pagar hasil pemuliaan berbasis pendekatan kuantitatif dan molekuler [Master Thesis]. Sekolah Pascasarjana Institut Pertanian Bogor. Retrieved from http://digilib. bppt.go.id/sampul/Tesis_Linda_Novita_A253 100011.pdf

Purwati, R. D., Sudarmo, H., \& Djumali. (2015). Adaptability of potential genotypes of Jatropha curcas L. as bioenergy source in three locations. Energy Procedia, 65, $317-$ 323. https://doi.org/10.1016/j.egypro.2015.01 .059

Raju, A. S., \& Bahadur, B. (2013). Breeding system and pollination in Jatropha curcas: an Overview. In Jatropha, challenges for a new energy crop: Volume 2: Genetic Improvement and Biotechnology. New York, NY, USA: Springer. https://doi.org/10.1007/978-1-46144915-7_3

Santoso, B. B. (2010). Deskripsi Botani jarak pagar (Jatropha curcas L.). Lombok: Arga Puji Press.

Santoso, B. B., Purwoko, B. S., \& Jaya, I. K. D. (2014). Yield of Jatropha curcas L. accessions of West Nusa Tenggara during five a year production cycle on a degraded agricultural land. Journal of Degraded and Mining Lands Management, 1(3), 123-130 https://doi.org/ 10.15243/jdmlm.2014.013.123

Surahman, M., Murniati, E., \& Misnen. (2010). Karakterisasi 10 genotipe jarak pagar (Jatropha curcas L.) lokal. Jurnal Ilmu Pertanian Indonesia, 15(1), 57-63. Retrieved from https://journal.ipb.ac.id/index.php/JIPI/ article/view/6591

Tar, M. M., Nyi, N., Tanya, P., \& Srinives, P. (2011). Genotype by environment interaction of Jatropha (Jatropha curcas L.) grown from seedlings vs cuttings. Thai Journal of Agricultural Science, 44(2), 71-79. Retrieved from https://www.researchgate.net/publicatio n/267393518_Genotype_by_Environment_Int eraction_of_Jatropha_Jatropha_curcas_L_Gro wn_from_Seedlings_vs_Cuttings

Taryono, Supriyanta, Putra, E. T. S., \& Yudono, P. (2019). Observasi pertumbuhan jarak pagar (Jatropha curcas L.) di lahan pasir pantai. Malang: BALITTAS. Retrieved from http:// balittas.litbang.pertanian.go.id/images/pdf/jp3 59.pdf

Tjitrosoepomo, G. (2010). Morfologi Tumbuhan. Yogyakarta: Gadjah Mada University Press.

Wijaya, A., Susantidiana, Harun, M. U., \& 
Surahman, M. (2013). Evaluasi Penampilan dan efek heterosis hasil persilangan beberapa aksesi jarak pagar (Jatropha curcas L.). Jurnal Agronomi Indonesia (Indonesian Journal of Agronomy), 41(1), 83-87. Retrieved from https://journal.ipb.ac.id/index.php/jurnalagron omi/article/view/7082

Wilde, S. A., \& Voigt, G. K. (2012). Munsell plant tissue color book. Grand rapids, Michigan, USA: Munsell Color Company. Grand rapids, Michigan, USA: Munsell Color Company.

Yahya, A., Hamdan, K., Ishola, T. A., \& Suryanto, H. (2013). Physical and mechanical properties of Jatropha curcas L. fruits from different planting densities. Journal of Applied Sciences, 13(7), 1004-1012. https://doi.org/ 10.3923/jas.2013.1004.1012

Yakub, S., Kartina, A. M., \& Isminingsih, S. (2013). Karakterisasi agro-morfologi aksesi jarak pagar asal setek di dataran rendah Banten. Jurnal Ilmu Pertanian dan Perikanan, 2(1), 1-9. Retrieved from https://adoc.pub/ disetujui-3-maret-2013.html

Yulaikah, S., \& Purwati, D. R. (2010). Karakterisasi morfologi plasma nutfah tanaman jarak pagar (Jatropha curcas L.). In Prosiding Lokarkarya Nasional V Inovasi Teknologi dan Cluster Pioneer Menuju DME Berbasis Jarak Pagar. Retrieved from https:// docplayer.info/29977190-Pjhosiidiinig-loka karya-niasionial-v-injq-vasi-tekniologi-dancluster-pioneer-men-ujiu-dme-berbasiis-jarakp-agiar-4-malalngj.html 